\title{
IMPROVING THE SECOND YEAR STUDENTS' SPEAKING ABILITY THROUGH PROJECT BASED LEARNING (PBL) AT MTSN MODEL MAKASSAR
}

\author{
Muhammad Saddam Abubakar \\ English Education Department Of Uin Alauddin Makassar \\ saddammuhammad975@yahoo.co.id
}

\begin{abstract}
This research was conducted to the second year students of MTsN Model Makassar in academic year 2014-2015. The subjects of this research consisted of thirty seven students. The objective of this research was to improve the students' speaking ability through Project Based Learning (PBL) method. This research applied Project Based Learning (PBL) to improve students' speaking ability. It is aimed to know the process teaching learning of using Project Based Learning (PBL) to improve students' speaking ability. The researcher used Classroom Action Research (CAR) as the research method. The researcher conducted two cycles; each cycle consisted of three meetings. The data were collected use three instruments. First instrument was observation sheet. The aims of this observation were to know the students' activity during the teaching and learning process, and to know the activeness of learning in improving the students' speaking ability, the second instrument was speaking test to measure the student's speaking skill improvement, and the last instrument was questionnaire to know the students' attitude toward project based learning (PBL).
\end{abstract}

KEY WORDS: speaking aspects, speaking activity, project-based learning

\section{A. INTRODUCTION}

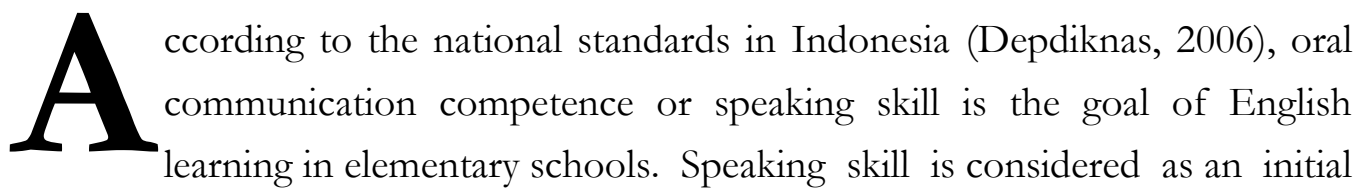

skill that leads learners to develop the other communication competences (reading and writing) (ibid.). This is in line with Linse (2005) saying that speaking is the first step that needs to be learned by young English language learners before they can read and write in English. However, it is assumed that developing speaking skill to young learners in Indonesia is not easy because of the status of English as a foreign language in which it is not used in national or social life (Broughton, 2003). 
An observation that I did in an elementary school in Northern Bandung, exactly in the Year 4 class, proved the difficulty of developing speaking skill in that school. The school was developing an English learning program to optimize the use of English in verbal context. However, English was still considered merely as a subject by the students so that the school needed to create situations that can improve the students' speaking skill.

In the view of this, Project based Learning (PBL) is one of the methods recommended to be used. PBL refers to a method allowing "students to design, plan, and carry out an extended project that produces a publicly exhibited output such as a product, publication, or presentation" (Patton, 2012:13). Through PBL, the learners are engaged in purposeful communication to complete authentic activities (project-work), so that they have the opportunity to use the language in a relatively natural context (Haines, 1989, as cited in Fragoulis, 2009) and participate in meaningful activities which require authentic language use (Fragoulis, 2009).

The success of PBL implementation has been reported by Gaer (1998) who taught speaking skill to a population of Southeast Asian refugees who had been in their beginning-level ESOL (English for Speaker of Other Language) classes. Their speaking skill is improved through PBL.

Viewing the success of PBL implementation to Asian refugees in the United States by Gaer, this study tries to apply PBL in Indonesian context, especially to young English learners. This study attempted to find out whether PBL could improve the students' speaking skill or not, what speaking aspects werre improved, and what speaking activities were used to improve the students' speaking skill. The scope of this study exposed the use of PBL in improving young English learners' speaking skill.

\section{B. LITERATURE REVIEW}

Darini (2013) conducted that in this study PBL improves the students' speaking skill. It was improved by the improvement of speaking aspect by Harries (1984) and Brown (2004) that is used as the framework of this study. Speaking aspects proposed by Harries and Brown that are improved through PBL are comprehension, vocabulary, grammar, fluency, and pronunciation.

Sifa Fauziah Permatasari (2010) conducted that according to the study on improving students' speaking skill through Project Based Learning for second year 
Muh. Saddam Abubakar, Improving The Second Year Students' Speaking Ability Through ...

of SMPN 1 Kawedanan, Magetan, the researcher comes to the conclusion that PBL could improve the students' speaking skill well.

Muhammad Riadh Gailea (2011) conducted of developing students speaking ability through pantomime in the second grade of SMA Negeri 1 Majene. the data shown that, before giving treatment the mean score of students' speaking was poor. It was proved that the total of raw score of students answer was 212,8 divided into total of sample then got the mean score was 5,5. It means that the students' speaking achievement is categorized into poor classification. And after giving treament through pantomime the speaking increase into fairly good level. This was proved that the total of raw score of students answer was 270 divided into total of sample then got the mean score 6,9. That prove that the students' speaking achievement increas into fairly good classification.

Muhaimin (2012) conducted a research at knowing the increasing of students' speaking ability through asking and answering technique at the second year of Madrasah Aliyah Putra As'adiyah Sengkang Kab. Wajo, where the subject of his research was limited to the class XII of Madrasah Aliyah Putra As'adiyah in academic year 2011/2012.

They consisted of 29 students. The researcher collected the data by giving pre test at the first meeting then applying the teaching action for three cycles. The result of the action shown the mean score of students' pre test before applying the technique was lower, but after applying the technique the mean score of students' was higher. So he concluded that Asking and Answering technique could increase the students' speaking ability.

Pitriani (2007) conducted a research on the role of Oral Production test in improving the students speaking ability found that the oral production test have many positive effects to the students' speaking ability such as, the students can be more active and fluently in speaking English, it can be proved from the result of pre test and post test, which is the pre test value is lower than the post test value.

Saharuddin (1991) did his research on developing the speaking ability of English education department of the second semester students at FPBS UNM Makassar through topic interest. The result of the research show that the students in interesting topic group can speak faster than the students in interesting clues. Consequently, the students can reduce many sentences in the interesting topic than in interesting topics in the some given time. In his study investigated the effects of Using Cooperative Learning strategy on developing oral communication skill of the 
first year students in the department of English at Port Said faculty of education. The result of his research showed that using cooperative learning was successful.

The researcher's finding above showed that project based learning (PBL) can be used to improve speaking ability can help the students to improve their speaking. In this research, the researcher introduced project based leaning (PBL) technique that can help students to improve their speaking.

\section{Definition of speaking}

Speaking is a process interaction between two or more people which producing good understanding each other. As stated by Byne (1984) says that oral communication is a process between speakers and listeners, involving the productive skill of speaking and the receptive skill of understanding. Both the speakers and the listeners have positive function to perform. The speakers has encode the message to be conveyed and appropriate language while the listeners (no less actively has to decode or interpret) the message.

To deal so far with the concept of oral skills, there are some definitions given by linguists and in the following:

Rahman (1995) stated that, speaking is a means of oral communication involving two elements, namely the speaker who gives the messages and the listener who receives the message in other words the oral communication involves the productive skill of speaking and the receptive skill of speaking.

Burns in Bachtiar (2006) speaking is a means of oral communication in expressing ideas, information and feeling to the others. It is the most essential way in which the speaker can express himself through a language. Learning to speak involves developing a number of complex skill and different types of knowledge about when and how to communicate. In the other words, speaking is used to communicate to the others.

From the definition above the researcher can conclude that speaking is sound and symbol produced by the speaker to communicate with the listener to share meaning.

\section{The Concept of Project Based Learning (PBL)}

\section{a. Definition of Project}

1) A project is a specific kind of a learning task, in which pupils are allowed to choose a topic and direction of its investigation. (Kasíková, 2001: 49)

2) A project is a task or a series of tasks that pupils should fulfill, mostly 
Muh. Saddam Abubakar, Improving The Second Year Students' Speaking Ability Through ...

individually but sometimes in groups. Pupils can often decide themselves how, where, when and in what order they will do the tasks. (Petty, 1996: 213)

3) Harmer says that projects involve investigation, reporting, commitment and dedication from students and the most important thing here is the endproduct. (Harmer, 1991: 147,148).

4) Project is defined as an in-depth investigation of a real world topic worthy of children's attention and effort

5) Project is defined as complex tasks based on problems encountered by students, conducted in certain periods of time and culminated in realistic products that might be in form of presentation, exhibition, publication, etc. (Thomas,2000).

6) The project is supposed to be long-term, requires teamwork among students, and results in a substantial final product (Thompson \& Beak, 2007, as cited in Cruz \& Vik, 2007).

\section{b. Definition of Project Based Learning (PBL)}

1) Project based learning is a teaching method in which students gain knowledge and skill by working for an extended period of time to investigate and respond to a complex question, problem, or challenge.

2) Project based learning (PBL) is complex tasks, based on challenging questions or problems, that involves students in design, problem-solving, decision making, or investigative activities; give the opportunity to work relatively autonomously over extended periods of time; and culminate in realistic products or presentations. (Thomas, 2000).

3) Project based learning (PBL) is a learning that focused to concept and facilitated students to investigate and decision a problem that happened (Santyasa, 2006).

\section{The Advantages of Project Based Learning (PBL)}

Fragoulis (2009) and Bell (2010) state that there are many benefits of implementing PBL in teaching English as Foreign Language:

a. PBL gives contextual and meaningful learning for students

b. PBL can create optimal environment to practice speaking English.

c. PBL can also make students actively engage in project learning

d. PBL enhances the students' interest, motivation, engagement, and enjoyment.

e. PBL promotes social learning that can enhance collaborative skills 
Volume I, Number 02, December 2015

f. PBL can give an optimal opportunity to improve students' language skill. The stages of Project Based Learning (PBL)

There are some stages of PBL implementation according to Kriwas (2010). They are:

1) Speculation, in which teachers provide the choice of project topics initially based on curriculum and discuss them with the students. In this stage, teachers and students speculate possibilities that will lead to the projects smoothly (Bell, 2010). However, for the beginner or lower level students, teachers can choose the project by themselves but still consider the students' problem. This was because it was assumed that "the students in beginner or lower level do not have the language or confidence to develop project themes" (Gaer, 1998) so that the teachers need to lead them first before they can decide by themselves.

2) Designing the project activities, referring to organizing the structure of a project activity that includes group formation, role assigning, concerning methodology decision, information source, etc (Bell, 2010).

3) Conducting the project activities, in which the students work what had been planned and designed in the previous stage. At this stage, the students gather information, discuss it with their group member, consult problems encountered in their work with the teachers, and exhibit their final products that might be in form of presentation, performance, product, publication, etc. to wider community such as other classes, teachers, foreigners, etc.

4) Evaluation

Fragoulis states "evaluation is the assessment of activities from the participants and discussion about whether the initial aims and goals have been achieved, implementation of the process, and final products"

\section{RESEARCH METHOD:}

The design of research used by the researcher in this study is classroom action research. According to Harmer, action research is the name given to a series of procedures teachers can engage in, either because they wish to improve aspects of their teaching, or because they wish to evaluate the success and or appropriacy of certain activities and procedures. Dave Ebbut stated that action research is about the systematic study of attempts to improve educational practice by group of 
Muh. Saddam Abubakar, Improving The Second Year Students' Speaking Ability Through ...

participants by means of their own practical action and by means of their own reflection upon the effects of those actions.

Arikunto stated that action research is one of the type investigation that has characteristic reflective participative, collaborative, and spiral that have purpose to repair and to increase the system, method, process, substance, competence, and situation.

Kemmis and Mc. Taggart add in Nunans' book explain that action research is a group of activity and a piece of descriptive research carried out by the teacher in his or her own classroom, without the involvement of others, which is aimed at interesting our understanding rather than changing the phenomenon under the investigation that would not be considered by these commentators to be 'action research', the essential impetus for carrying out action research is to change the system.

From all the definitions above, the researcher concluded that classroom action research is a classroom action in a research, which can be done by teacher, researcher, and teacher with his or her colleague, etc with involves a group of students to improve teaching and learning process or to enhance the understanding of the students to the lesson. Thus, by using this method, it was expected that this study could investigate, analyzed, and explained students' speaking ability using Project Based Learning (PBL).

\section{Characteristics of Classroom Action Research}

Kemmis and Mc. Taggart in Nunan's book argue that there were three defining characteristic of action research:

a. It is carried out by practitioners (for our purposes, classroom teachers) rather than outside researchers.

b. It is collaborative

c. It is aimed at changing things

\section{Aim of Classroom Action Research}

There are many possible reasons for conducting a classroom action research as follow: we want to know more about our learners and what they find motivating and challenging.

We want to learn more about ourselves as teachers how effective we are, how we look to our students, how we would look to ourselves if we were observing our own teaching. We want to gauge the interest generated by certain topics, or 
judge the effectiveness of certain activity types. We want to see if an activity would work better done in groups rather than pairs, or investigate whether reading is more effective with or without pre-teaching vocabulary.

In other word, can be said that by doing an action research, teacher develop their skills in giving the material to the students. They have challenge to solve the problem that they have found in the class. They have inner motivation to do this research because they aware of their advantages, their class situation need a spiral treatments and a direct action. Therefore, this situation creates a good environment among teachers to do the best thing for the students.

Action research is regularly done to improve a learning process. With this research, the teacher will know his or her weakness in teaching their students. They will know the effective methods in teaching speaking.

\section{Procedures of Classroom Action Research}

According to Jeremy Harmer, there are four components in one cycle for conducting classroom action research. It consists of planning, action, observation, and reflection.

The four phases of the classroom action cycle were conducted integrated like spiral. Each phase was concluded based on the previous one and the next. It means that the activities in the classroom action research were based on planning, action, and observation, then, the researcher could make a reflection to determine the next cycle.

\section{THE SCHEME OF CLASSROOM ACTION RESEARCH}

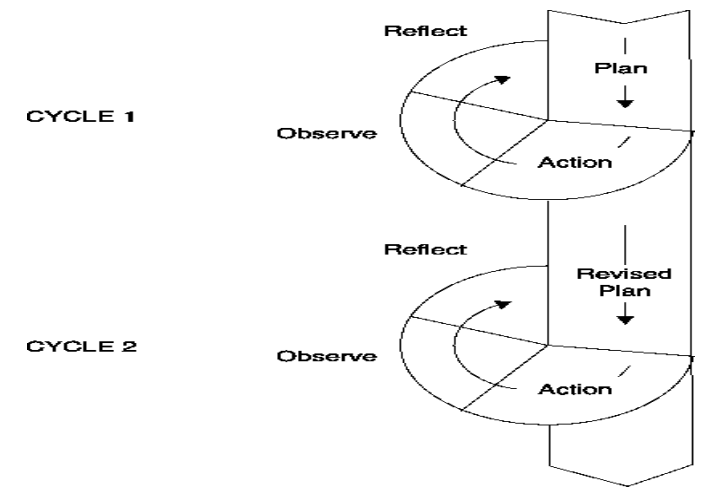

Figure 1: The cycle of CAR adapted from Kemmis and McTaggart (Arikunto, 2010)

This research consists of two cycles. Each cycle consisted of four meetings. Each cycle consisted of four stages. The descriptions were: 
Muh. Saddam Abubakar, Improving The Second Year Students' Speaking Ability Through ...

\section{a. First cycle:}

\section{Planning}

This step, the researcher prepared what the students have to do in the action step. All planning included lesson plan, made syllabus, pre-test and post-test assessment tools, media or teaching aids, observation sheet, and instrument test, to be used in the classroom during PBL implementation.

\section{Acting}

a) Gave expression and vocabularies needed

b) Explained the materials and instruction for practicing

c) Practiced and performed in the front of the class

d) Evaluated and gave general conclusion

\section{Reflecting}

a) Evaluated the teaching and learning process

b) Analyzed the students' achievement

c) Revise the lesson plan for the next cycle

\section{Observing}

a) Observed the students' participation

b) Observed the students' achievement

b. Second cycle:

\section{Planning}
a) Revised lesson plan and modify the technique
b) Reselect the materials
c) Prepare the observation checklist for the students
d) Prepare the questionnaire and post-test 2

\section{Acting}
a) Review the previous material
b) Gave the topic
c) Group work
d) Students perform role play in the front of class
e) Evaluated and gave general conclusion

\section{Reflecting}

a) Analyzed the students' progress in speaking based on the score students got in post-test 2 
b) Analyzed the students' response based on the questionnaire result

\section{Observing}

a) Observed the students' achievement

b) Observed the students' participation

\section{FINDING AND DISCUSSION}

\section{Students' Participation}

Students' participation from the first cycle to the second cycle increased significantly. Project-Based Learning implemented in the class helped the students to become more active in the class. Project Based Learning that was implemented in a group discussion helped the students to increase their participation.

The comparison of the students' participation in first cycle and second cycle was significantly increased. In the first cycle, the participant students who actively involved in learning activities aspect were 22 students or $59 \%$ of the students. In other hand, there were 35 students actively involved in the cycle two or $92 \%$. Based on the result, there were increased around 33\%. In feeling of happiness aspect showed that score students in happy in learning process were 12 students or $32 \%$ of the students, and in second cycle the score of the students were 28 students or $76 \%$ of the students. Based on the result, there were increased around $44 \%$ in feeling of happiness aspect. And then, in interaction aspect's showed that participant students improved.

In the first cycle the students who actively were 13 students or $35 \%$ of the students. In other hand, there were 35 students or $92 \%$ of the students in second cycle. Based on the result, there were increased around 57\%.

The increasing of students' participation was the effect of the implementation of Project Based Learning

\section{The Students' Performance}

The students' performance from the pre-cycle until second-cycle was significantly increased. For pre-cycle, the mean score students who performed in front of the class and also answer the researcher's question were $1.62 \%$. The students also had low score for their performance. In the last meeting of the first-cycle, the mean score of students were $2.59 \%$. It means that students' performance were bit increased. All of the students had to perform in this cycle, but the result of their performance still low. The students' fluency and comprehensibility were still in low 
Muh. Saddam Abubakar, Improving The Second Year Students' Speaking Ability Through ...

level. In the second cycle, the students' performance got better than before. The researcher helped them to improve their speaking ability during teaching learning process.

\section{E. CONCLUSION AND RECOMMENDATION:}

\section{Conclusion}

Based on the findings on the discussion, the researcher concluded that the students' speaking ability at the second year students of MTsN Model Makassar tends to be improved after applying project based learning (PBL) as a method.

a. The implementation of Project Base Learning (PBL) can improve the students' speaking ability through the participation, performance and project in Project Based Learning (PBL). Students' participation in the project assigned by the teacher has helped them to be more active in asserting their ideas. Through performance, the students are enabled to be actively involved in presenting and giving feedback which are acquired from small and big group discussion. Through the project, the students could interact with their friends in small group before the students spoke in a big group to enhance their speaking ability.

b. The students' attitude towards Project Based Learning (PBL) implementation is generally positive as the students seemed to enjoy the discussion and the performance based on what the students had made through the project assigned by the teacher.

\section{Recomendation}

Based on the result of the conclusion, the researcher would like to give suggestion as follows:

a. For the teacher, as Project based learning (PBL) is proved to be able to improve students' speaking ability through participation, performance and project, it is highly recommended to be used in teaching speaking in junior high school or in higher levels, and as Project Based Learning is accepted positively by the students, it motivates and can help students to be more active in expressing their ideas with confidence, present and give feedback in small and big discussions, and enhance their speaking ability by interacting with their friends prior to the big group discussion.

b. For the researcher, as this is a small scale classroom action research, experiment research can be used by other researchers in a wider setting to verify the findings 
of this current research. More development of activity variations can be made in certain variables of Project Based Learning, including the time span in implementing the Project Based Learning. Other areas of language micro skills improvement either discretely or integrated using Project Based Learning can also be examined to maximize students' potentials in their language ability.

\section{REFERENCES:}

Arikunto, Suharsimi, et. al.. (2008). Penelitian Tindakan Kelas. Jakarta: PT Bumi Aksara.

Arikunto, Suharsimi. (2008). Prosedur Penelitian Suatu Pendekatan Praktik. Jakarta: PT. Rineka Cipta, Edisi Revisi VI.

Bahtiar. (2006). Reducing Speaking Anxiety Through Various Communicative Activities. Thesis. Makassar: FBS UNM.

Bell, S. (2010). Project-Based Learning for the 21st century: skill for the future. The Cleaning House, 83:39-43.

Brown. (2001). Teaching the Spoken Language. Cambridge: Cambridge University Press.

Byrne (1984). Teaching Oral English. New York: Longman inc.

Cameron, L. (2001). Teaching Language to Young Learners. Cambridge: Cambridge University Press.

Darini. (2013). The Use of Project-Based Learning in Improving the Students' Speaking Skill. Thesis. Bandung: University of Education.

David Nunan. (1993). Research Method in Language Learning, (Cambridge: Cambridge University Press), p.18.

Dobson, Julia. (1975). Dialogues: Why, When, and How to Teach Them ET Forum. Volume XII number 1 and 2.USA.

Fauziah. (2010). Improving Students' Speaking Skill through Project-Based Learning. Thesis. Magetan.

Fragoulis, L. (2009). Project-Based Learning in Teaching of English as A Foreign Language in Greak Primary Schools: Ftom Theory to Practice. (A Journal). English Language Teaching. Vol. 2 September 2009.

Gailea. (2011). Developing Students Speaking Ability through Pantomime. Thesis. Makassar: UIN Alauddin.

Harun, Y. (2006). Project-Based Learning handbook "Educating the Millennial Learner". Kuala Lumpur: Educational Technology Division Ministry of Education.

Hornby. (1995). Oxford Dictionary. Oxford Dictionary Press. 
Muh. Saddam Abubakar, Improving The Second Year Students' Speaking Ability Through ...

Hughes, A. (1992). Testing for Language Teachers. British: Cambridge University Press.

James H. McMillan and Sally Schumacher. (2006). Research Education: Evidence-Based Inquiry, (New York: Pearson Education), p. 194.

Jeremy Harmer. (2003). The Practice of English Language Teaching, (England: Longman), P. 344.

J.B. Heaton. (1990). Classroom Testing: Longman Keys to Language Teaching, (New York: Longman), p. 70-71

Kayi, H. (2006). "Teaching speaking: activities to promote speaking in a second language". The Internet TESL Journal, Vol. XII, No. 11, November http://unr.edu/homepage/hayriyek

Kemmis, S., \& McTaggart, R. (1990). The Action Research Planner. Victoria: university press.

Mansoor, I. (1997). Project Based Learning and Assessment: A Resource Manual for Teachers. Virginia: Arlington Education and Employment Program.

Muhaimin. (2012). The Increasing of Students' Speaking Ability through Asking and Answering Technique at the Second Year of Madrasah Aliyah Putra Sengkeang Kab. Wajo.Thesis. Makassar: UIN Alauddin.

Patton, A. (2012). Work That Matters: The Teacher's Guide to Project-Based Learning. The Paul Hammy In Foundation.

Pitriani. (2007). Improving the Students' Speaking Ability through Oral Production test. Thesis. Makassar: UNM.

Rahman. (1995). Increasing the Students' Speaking Interest in Studying Speaking through Oral Communicative Activities. Retrived on january 2014 from http://www.call.org/caela/diegest/beginQA.htm

Saharuddin. (1991). Developing the Speaking Ability of English Edeucation Department of the Second Students at FP BS UNM Makassar through Topic Interest. Makassar:UNM.

Santyasa, I. Wayan. (2006). Pembelajaran Inovatif :Model Kolaboratif, Basis Proyek dan Orientasi NOS. (online), (http://www.pembelajaran Inovativ $\backslash 2006 . h t m l, 13$ Oktober 2011).

Sudjana. (2002). Metode Statistika. Bandung: PT. Tarsito, p. 67.

Syamsudin AR and Vismaia S. Damaianti. (2006). Metode Penelitian Pendidikan Bahasa, (Bandung: PT Remaja Rosdakarya), p. 161.

Thomas, J.W. (2000). A Review of Research on PBL. California: The Autodesk Foundation. 